Ryszard Nowicki

Bydgoszcz

\title{
Rola Józefa Grycza w powojennej ochronie zbiorów bibliotecznych
}

Na ziemiach polskich, wraz z postępującym w 1944 r. na zachód wojskiem, rozpoczęto odbudowę zniszczonego działaniami wojennymi kraju. Do niezwykle ważnych zadań należała ochrona księgozbiorów, która została wówczas zapoczątkowana. Ratowaniem druków i rękopisów zajęły się resorty: Informacji i Propagandy, Kultury i Sztuki, Oświaty, Rolnictwa i Reform Rolnych, a także Wojsko Polskie, partie polityczne, organizacje młodzieżowe, spółdzielcze oraz inne ${ }^{1}$. Jak stwierdził Józef Janiczek, który w Lublinie przystąpił do ocalania zbiorów: „każdy z tych czynników tylko siebie uważał za najbardziej powołany do zabezpieczania książek" 2 . Praca nie była skoordynowana. Na początku listopada 1944 r. Resort Oświaty opracował projekt dekretu o zabezpieczaniu księgozbiorów opuszczonych ${ }^{3}$. Nie doszło jednak do jego uchwalenia.

Główne działania ochronne, określone mianem akcji zabezpieczenia zbiorów bibliotecznych, trwały w latach 1945-19494. Czynności, jak wspomniano, podejmowały różne instytucje ${ }^{5}$, jednak największe osiągnięcia odnotowało Ministerstwo Oświaty, w wyniku planu nakreślonego i realizowanego przez Józefa Grycza.

${ }^{1}$ J. Janiczek, Sprawy biblioteczne w ramach działalności Ministerstwa Oświaty, „Bibliotekarz", 13:1946, nr 1-2, s. 3.

2 Tamże.

3 Tamże, s. 4.

4 Problem powojennej ochrony zbiorów bibliotecznych w Polsce nie doczekał się jak dotychczas naukowego opracowania monograficznego. Brakuje również artykułów dotyczacych tego zagadnienia - por. R. Nowicki, Metody badań nad problematyka ochrony zbiorów bibliotecznych po II wojnie światowej, [w:] Bibliologia. Problemy badawcze nauk humanistycznych, pod red. D. Kuźminy, Warszawa 2007, s. 255.

${ }^{5}$ Pierwszym dokumentem był Rozkaz nr 120 Naczelnego Dowódcy Wojska Polskiego $z 22$ XI 1944 r., który nakazywał żołnierzom zabezpieczać m.in. cenne podręczniki i książki naukowe (Centralne Archiwum Wojskowe w Warszawie, sygn. III.5.197, k. 36). Władze wojskowe wszelako, ze względu na toczone ciężkie walki z Niemcami, nie były w stanie podjąć zorganizowanych działań związanych z ochroną księgozbiorów. 
Bibliolog ten w okresie międzywojennym był dyrektorem Biblioteki Kórnickiej i współzałożycielem „Przeglądu Bibliotecznego”. Należał do grona współorganizatorów Biblioteki Narodowej. 1 stycznia 1930 r. został mianowany radcą w Ministerstwie Wyznań Religijnych i Oświecenia Publicznego. Pracował tam jako referent spraw bibliotek naukowych. Pozostał na tym stanowisku do likwidacji Ministerstwa przez władze hitlerowskie na początku II wojny światowej. Później przeniesiono go do Biblioteki Narodowej. Po zamknięciu placówki rozpoczął w konspiracyjnych warunkach pracę, która polegała m.in. na rejestracji wojennych szkód w bibliotekach. Uczestniczył w tajnym nauczaniu. Na rozkaz władz okupacyjnych, i za zgodą polskiego podziemia, 27 lipca 1940 r. objął kierownictwo ${ }^{6}$ tzw. II Oddziału Staatsbibliothek Warschau (tj. Biblioteki Narodowej). Dwa lata później, w kwietniu 1942 r., skreślił do Adama Łysakowskiego następujące słowa: „Życie moje niełatwe, ale robię, jak umiem najlepiej z myślą o przyszłości, zarówno gdy chodzi o B[ibliotekę] Nar[arodową] jak w ogóle o dawne moje 'gospodarstwo' [tj. bibliotekarstwo]. Robię plany i programy, staram się dowiedzieć, jaki stan moich dawnych pupilów - ludzi i zbiorów, trzeba się przygotować na jutro i na dalszą metę. Życie płynie i przynosi zmiany, trzeba się z tym liczyć"7. Józef Grycz zdawał sobie doskonale sprawę, że wojna się skończy. Wówczas trzeba będzie niezwłocznie przystąpić do planowego, kierowanego centralnie, ratowania księgozbiorów oraz odbudowy bibliotek.

W Bibliotece Narodowej pracował do 25 października 1944 r. Następnie trafił do obozu w Pruszkowie, z którego po trzech dniach wydostał się i wyjechał do Krakowa. Na początku listopada, na wezwanie władz polskich, przybył do Pruszkowa i objął kierownictwo grupy zabezpieczającej i wywożącej zbiory biblioteczne z Warszawy ${ }^{8}$. Prowadził czynności w Bibliotece Narodowej do 31 marca 1945 r., to jest powrotu jej dyrektora Stefana Wierczyńskiego. Po kilku latach wspominał: „Po wyzwoleniu 2 II 1945 [r.] wróciłem do Warszawy i kierowałem pracami w Bibliotece Narodowej, zabezpieczając drzwi i okna, usuwając śnieg z książek, porządkując zbiory przy pomocy kilkunastu pra-

${ }^{6}$ J. Grycz - Materiały biograficzne; Życiorys, Warszawa 28 IX 1951, BN, rps akc. 14917 (rękopisy ze spuścizny Gryczów jak dotychczas nie otrzymały foliacji).

${ }^{7}$ J. Grycz do A. Łysakowskiego, [Warszawa] 12.04.1942, [w:] Bibliotekarstwo polskie 1925-1951 w świetle korespondencji jego wspóttwórców, wyboru z listów Adama Łysakowskiego, Mariana Łodyńskiego, Józefa Grycza i Heleny Hleb-Koszańskiej dokonała, wstępami, przypisami i indeksem opatrzyła M. Dembowska, Warszawa 1995, s. 274.

${ }^{8}$ M. Łodyński, Pruszkowska akcja zabezpieczania warszawskich zbiorów bibliotecznych (1944-1945). Wspomnienia uczestnika akcji, [w:] Walka o dobra kultury. Warszawa 1939-1945, pod red. St. Lorentza, Warszawa 1970, t. 2, s. 266-282. 
cowników"9. Podobnie sytuacja wyglądała w wielu innych ocalałych placówkach na terenie kraju. Prace należało rozpocząć od zabezpieczenia samego gmachu bibliotecznego.

1 kwietnia 1945 r. został mianowany wizytatorem szkół w Wydziale Bibliotek Ministerstwa Oświaty. Pełnił również obowiązki kierownika Referatu Ogólnego wspomnianego Wydziału ${ }^{10}$. W wyniku podjętych wysiłków i determinacji przyczynił się do utworzenia 12 marca 1946 r. pierwszej w historii polskiego bibliotekarstwa instytucji koordynującej działania wszystkich typów bibliotek, tj. Naczelnej Dyrekcji Bibliotek ${ }^{11}$. Od 1 kwietnia 1946 r., jako naczelny dyrektor bibliotek, kierował tą placówką. Do głównych zadań powstałej centralnej władzy wykonawczej Ministerstwa Oświaty należało prowadzenie akcji zabezpieczenia zbiorów. Zredagował tekst pierwszej w dziejach Polski ustawy o bibliotekach i doprowadził, wspólnie z Józefem Janiczkiem, do jej uchwalenia 17 marca 1946 r. W myśl zapisu dekretu Ministerstwo Oświaty sprawowało naczelny nadzór i opiekę nad bibliotekami i zbiorami bibliotecznymi. W Ministerstwie pozostał do 1949 r. Od 1 marca tego roku, po zwolnieniu, pracował na stanowisku zastępcy dyrektora Biblioteki Narodowej.

Powróćmy do kwestii związanej z powojenną ochroną i zabezpieczeniem zbiorów bibliotecznych. Trzeba przyznać, że współtwórca nowoczesnego polskiego bibliotekarstwa miał dobrze nakreślony plan działania oraz szybko zdobył doświadczenie praktyczne, jeszcze podczas okupacji. Słusznie wówczas przewidywał: „po wojnie będzie taki brak książek, dawnych i współczesnych, że każdą, która ocaleje, trzeba będzie nie tylko ratować i chronić, ale i udostępniać czytelnictwu" ${ }^{12}$. Za pierwsze i niezbędne zadanie uznał zabezpieczenie zbiorów bibliotecznych ${ }^{13}$.

Kilka dni po oswobodzeniu Warszawy, 21 stycznia 1945 r., Rada Miejska Narodowa, funkcjonująca wówczas na Pradze, upoważniła Józefa

\footnotetext{
${ }^{9}$ J. Grycz - Materiały biograficzne; Życiorys, Warszawa 28 IX 1951 - BN, rps akc. 14917.

${ }^{10} \mathrm{~W}$ pierwszej połowie kwietniu 1945 r., w liście skierowanym do Aleksandra Birkenmajera, wyjaśniał sytuację w Ministerstwie Oświaty. Przekazywał wiadomość, że Naczelnikiem Bibliotek jest Józef Janiczek. O sobie natomiast napisał: ,ja zaś jestem 'ministerialnym wizytatorem szkól' [sic!] i kierownikiem referatu ogólnego w Wydziale Bibliotek" (J. Grycz do A. Birkenmajera, Warszawa, 13 IV 1945 - BJ rps, Przyb. 572/75).

11 Nie było to zadnie łatwe, m.in. z powodu braku fachowców: „Moje nowe kłopoty już się zaczęły, próbuję montować Naczelną Dyrekcję Bibliotek, ale brak ludzi utrudnia wszystko" (J. Grycz do A. Birkenmajera, Warszawa 28 III 1946, BJ rps, Przyb. 572/75).

12 J. Grycz, Wskazówki dla prowadzacych akcje zabezpieczenia bibliotek i zbiorów bibliotecznych, Warszawa-Poznań 1945, s. 12.

13 J. Grycz - Materiały do działalności publicznej; Biblioteka, [Warszawa] 1946 - BN, rps akc. $14927 / 3$.
} 
Grycza do „zaopiekowania się majątkiem ruchomym i nieruchomym Biblioteki Narodowej w Warszawie"14. Dwa dni później warszawski Wojewódzki Urząd Bezpieczeństwa Publicznego zezwolił Józefowi Gryczowi przejść na lewy brzeg Wisły i poruszać się swobodnie po mieście oraz całym obszarze województwa warszawskiego ${ }^{15}$. Natomiast Inspektorat Szkolny Miasta Stołecznego Warszawy, powołując się na zarządzenie Resortu Oświaty, upoważnił go 28 lutego 1945 r. do ,zabezpieczenia ew. wywiezienia księgozbiorów prywatnych pozostających bez opieki" ${ }^{16} \mathrm{w}$ stolicy.

Wspomniane zarządzenie Resortu Oświaty, wydane 29 XI 1944 r. ${ }^{17}$, w sprawie zabezpieczenia bibliotek i zbiorów bibliotecznych, nakładało na władze szkolne I i II instancji, czyli inspektoraty i kuratoria szkolne, obowiązek ochrony księgozbiorów. Resort Oświaty, a następnie Ministerstwo Oświaty było jedną z wielu instytucji uczestniczących w ratowaniu dzieł. Nie sprzyjało to zorganizowanej i planowej pracy w skali kraju. Zbiory biblioteczne dzielono nie bacząc na ich proweniencję, przekazywano bez żadnej dokumentacji, czy też przywłaszczano. Przewidział tę wyjątkowo trudną sytuację Józef Grycz, który w warunkach okupacyjnych, nakreślił podstawy teoretyczne oraz wskazał na rozwiązania praktyczne ${ }^{18}$. Elementem charakterystycznym zawodowej aktywności bibliologa stało się bowiem łączenie teorii z praktyką.

W ramach prac konspiracyjnych opracował, wydane w 1945 r., Wskazówki dla prowadzacych akcję zabezpieczenia bibliotek $i$ zbiorów bibliotecznych. Była to pozycja wyjątkowa w powojennym repertuarze wydawniczym. Działania ochronne, w zamyśle jej autora, miały stanowić niezwykle ważny etap do osiągnięcia głównego celu, tj. odbudowy polskich bibliotek. „Wobec spustoszenia, jakiego niemieccy okupanci dokonali w naszych księgozbiorach, musimy niezwłocznie przystąpić do zabezpieczenia zachowanych zbiorów i podjąć odbudowę bibliotek. Ta odbudowa musi być prowadzona planowo i etapami" - twierdzi ${ }^{19}$.

Prace należało oprzeć o przepisy prawne. We Wskazówkach autor podał, że jako podstawa akcji zabezpieczenia bibliotek i zbiorów biblio-

${ }^{14}$ J. Grycz - Materiały biograficzne, Upoważnienie z 21 I 1945 r. - BN, rps akc. 14917.

15 Tamże.

16 Tamże.

${ }^{17}$ Okólnik Resortu Oświaty w sprawie zabezpieczenia bibliotek i zbiorów bibliotecznych, Nr Bbl. IV - W - 2195/44, „Dziennik Urzędowy Resortu Oświaty”, 1944, nr 1/4, poz. 32.

${ }_{18}$ A. Kawecka-Gryczowa, Ochrona zbiorów Biblioteki Narodowej, [w:] Walka o dobra kultury. Warszawa 1939-1945, pod red. S. Lorentza, Warszawa 1970, t. 1, s. 240; B. Bieńkowska, Potyczki ze źródtami bibliologicznymi, „Roczniki Biblioteczne”, 45:2001, s. 8-9.

${ }^{19}$ Wskazówki dla prowadzących akcję zabezpieczenia bibliotek i zbiorów bibliotecznych, Warszawa-Poznań 1945, s. 3. 
tecznych może służyć okólnik Ministerstwa Oświaty z 29 XI 1944 r. Tutaj wkradła się drobna nieścisłość - zapewne wynikała ona z pośpiechu związanego z przygotowaniem i oddaniem książki do druku - okólnik bowiem został wydany jeszcze przez Resort Oświaty PKWN, który przemianowano na Ministerstwo Oświaty dopiero z dniem 1 stycznia $1945 \mathrm{r}$. O innych nowych dokumentach prawnych nie wspomniał. Nie miał natomiast najmniejszych wątpliwości, iż zostaną one opublikowane ${ }^{20} . \mathrm{Pu}-$ blikacja miała zatem charakter w pełni nowatorski. Nie tylko wyjaśniała oraz wskazywała jak prowadzić czynności, ale także zapowiadała wydanie przez stosowne władze zapisów regulujących ochronę zbiorów bibliotecznych, ujętych w ustawach, zarządzeniach, czy instrukcjach. Formułując ogólne dyrektywy napisał:

\begin{abstract}
Akcją objąć należy cały oswobodzony obszar Polski. Pierwsze zadanie, to zarejestrowanie wszelkich bibliotek na danym terenie oraz wszystkich strat i szkód, jakie poszczególne biblioteki i zbiory poniosły czy to w wyniku bezpośrednich działań wojennych, czy podczas okupacji wskutek zniszczenia lub zabrania książek przez okupanta lub okoliczną ludność, przez pozostawienie w nieodpowiednich pomieszczeniach itd. [...] Konkretne prace ratownicze muszą być podjęte niezwłocznie po ustąpieniu okupanta, nie czekając na przeprowadzenie rejestracji strat. Chodzi mianowicie o ratowanie zbiorów, które ocalały czy to w dawnym lokalu bibliotecznym, czy w innych pomieszczeniach i kryjówkach, czy też wśród obcych. Te ostatnie będą to książki bądź dawniej wypożyczone, bądź zabrane $\mathrm{z}$ bibliotek $\mathrm{w}$ celu ochronienia ich przed zniszczeniem lub rozgrabieniem, bądź wreszcie, niestety, przywłaszczone bezprawnie wskutek pozostawienia księgozbioru bez dozoru, lub w związku z wyrzucaniem przez okupantów książek z bibliotek na przepadłe. $\mathrm{W}$ każdym $\mathrm{z}$ tych przypadków postępowanie, taktyka, musi być z natury rzeczy inna. Zawsze jednak trzeba będzie starać się dojść przynależności poszczególnej książki do określonego zbioru i ustalić prawa własności²1.
\end{abstract}

\title{
Józef Grycz trafnie oceniał, iż:
}

Główna część akcji z natury rzeczy dokonywać się będzie „w terenie”. Niewątpliwie od razu, skoro tylko okupant opuści daną okolicę, właściciele i zarządy bi-

${ }^{20} \mathrm{O}$ ich ogłoszeniu w niedalekiej przyszłości był przekonany: „Przypominam, że mowa tu o pierwszym okresie po ustaniu okupacji, o ratowaniu księgozbiorów szkolnych i oświatowych i o pierwszych krokach na drodze ku ich odbudowie. Dalsze postępowanie unormują już zarządzenia właściwych władz i organów bibliotecznych" (s. 9). Dalej autor wyjaśniał: „Na razie chodzi o program natychmiastowy, o zorganizowanie tymczasowej, doraźnej akcji po prostu 'ratowniczej', zanim zorganizowane będą właściwe władze konserwatorskie i biblioteczne, zanim rozpocznie się oficjalna planowa odbudowa naszego bibliotekarstwa" (s. 12).

21 Tamże, s. 5- 6. 
bliotek rozpoczną w własnym zakresie kroki, aby rozbite zbiory schronić w bezpiecznym pomieszczeniu, a nade wszystko, aby odzyskać rozproszone. Niezależnie od tych „prywatnych” poczynań jak najrychlej należy podjąć planową i oficjalną akcję przy pomocy specjalnie do niej zaangażowanych i przygotowanych pracowników. Ci pracownicy, zaopatrzeni w specjalne mandaty i upoważnienia, oraz zgody z otrzymanymi poleceniami i instrukcjami, zgłoszą się, każdy do wyznaczonej biblioteki lub kilku bibliotek znajdujących się blisko siebie i, w porozumieniu z właścicielami, najpierw zbadają stan księgozbioru, potrzeby i możliwości jego odbudowy, dowiedzą się, co w tym kierunku było już podejmowane i z jakim wynikiem, po czy, przystąpią do działania ${ }^{22}$.

Ochrona dotyczyła wszystkich typów bibliotek, w tym szkolnych oraz powszechnych:

Ksiądz, nauczyciel, miejscowi działacze społeczni w ogóle, a przede wszystkim starsza zorganizowana młodzież mają tu wdzięczne pole pracy. Stosowne pisemne pełnomocnictwa, wydane przez właściwy ośrodek odbudowy, powinny tym drużynom ochotniczym utorować dostęp do rozproszonych i ukrytych książek, a ścisłe instrukcje wskazać sposób postępowania przy ich odzyskiwaniu i dalszym zużytkowaniu ${ }^{23}$.

Zaangażowanie duchownych i ich wymienienie w 1945 r. było jeszcze możliwe. Wkrótce, ze względu na wprowadzanie nowego ustroju w Polsce, znikną oni ze stron gazet i książek. Natomiast przedstawiona propozycja, dotycząca pisemnych pełnomocnictw, będzie miała zastosowanie.

Dużą wagę i znaczenie przywiązywał do bibliotek, określonych mianem zabytkowych oraz naukowych:

Należą tu przede wszystkim biblioteki przechowywane w naszych dworach ziemiańskich. Sięgają one swymi początkami nieraz daleko w przeszłość, narastały w ciągu wielu dziesiątków lat, przekazywane z pokolenia na pokolenie. Nieliczne tylko były przed wojną udostępnione uczonym. A wystarczy przecież przeczytać bodaj Zbiory polskie E. Chwalewika ${ }^{24}$ lub pracę zbiorową Biblioteki wielkopolskie i pomorskie ${ }^{25}$, Poznań 1926 [!], aby dowiedzieć się, jak cenne i dla dostępu nauki niezbędne materiały posiadały. Podobnie niedostępne lub udostępnione tylko w wyjątkowych przypadkach były również biblioteki duchowne (diecezjalne, kapitulne, seminaryjne, klasztorne $)^{26}$.

22 Tamże, s. 12-13.

23 Tamże, s. 6-7.

${ }^{24}$ Edward Chwalewik, Zbiory polskie: archiwa, bibljoteki, gabinety, galerje, muzea $i$ inne zbiory pamiatek przeszłości $w$ ojczyźnie i na obczyźnie w porzadku alfabetycznym według miejscowości utożone, t. 1: A-M, Warszawa 1926 [oraz] t. 2: N-Ż, Warszawa 1927.

${ }^{25}$ Biblioteki wielkopolskie i pomorskie, pod red. S. Wierczyńskiego, Poznań 1929.

${ }^{26}$ J. Grycz, Wskazówki..., s. 10. 
Przewidywał wystąpienie w powojennej rzeczywistości niekorzystnego zjawiska, tj. szabru. Wobec tego postulował „wydanie zakazu sprzedawania i kupowania książek z pieczątkami lub innymi znakami, wskazującymi, że należą one do jakiegoś księgozbioru, oraz skrupulatne kontrolowanie tego, zapobiegnie dalszemu rozpraszaniu bibliotek"27. Propozycja była słuszna. Podejmowane działania w tym zakresie nie przyniosły jednak pozytywnego rezultatu ${ }^{28}$.

Prace miały polegać na zbieraniu wszelkich informacji o bibliotekach, zabezpieczaniu księgozbiorów, segregacji oraz repartycji dzieł. Autor wskazywał miejsca do składowania materiałów bibliotecznych, szczegółowo instruował, jak należy z nimi dalej postępować. Czynności związane z gromadzeniem zbiorów zaliczył do pierwszego etapu. Kolejny polegał na ich porządkowaniu. Informacje te stanowiły zapowiedź działań podjętych wkrótce przez Józefa Grycza w ramach Naczelnej Dyrekcji Bibliotek. Akcję zabezpieczania i ochrony księgozbiorów w Polsce podzielono na dwa etapy: pierwszy z nich trwał do końca 1946 r. i polegał głównie na ochronie oraz zabezpieczeniu zbiorów, drugi natomiast, rozpoczęty po utworzeniu na początku 1947 r. na terenie kraju kilku zbiornic-sortowni, na segregacji i rejestracji dzieł oraz podziale zgromadzonych książek.

Czy postulaty zawarte we Wskazówkach znalazły zastosowanie w praktyce? Powojenna ochrona zbiorów bibliotecznych w Polsce odbywała się $\mathrm{w}$ oparciu o przyjęte dokumenty prawne. Zawarte natomiast w publikacji informacje stanowiły istotne wsparcie dla ratowników książki działających w terenie. Przykładowo jednym z nich był dyrektor Biblioteki Uniwersyteckiej w Poznaniu Aleksander Birkenmajer ${ }^{29}$, któremu podlegał obszar Wielkopolski oraz częściowo Pomorza Zachodniego i Dolnego Śląska. W Sprawozdaniu Biblioteki Uniwersyteckiej w Poznaniu za lata 1945-1946 odnotowano: „Pomocą służyły tu 'Wskazówki dla zabezpieczających', broszura wydana przez dr. J. Grycza, podług której rozplanowano pracę"30. A polegała ona głównie na:

- zbieraniu wiadomości o bibliotekach,

- zabezpieczaniu księgozbiorów,

27 Tamże, s. 7.

${ }^{28} \mathrm{O}$ bezprawnym przywłaszczaniu książek donosiła m.in. ówczesna prasa; por. R. Nowicki, Powojenna ochrona zbiorów bibliotecznych na tamach prasy, [w:] Od ksiązki dawnej do biblioteki wirtualnej, pod red. D. Degen i M. Fedorowicz, Toruń 2009, s. 279-296.

${ }^{29}$ R. Nowicki, Działalność Aleksandra Birkenmajera na rzecz ochrony zbiorów bibliotecznych. Ziemie zachodniej i pótnocnej Polski w latach 1945-1947, Poznań 2006.

${ }^{30}$ Poznań, Biblioteka Uniwersytecka, sygn. IV 104 887, s. 103. 
- zbiórce książek,

- segregacji książek,

- współpracy z innymi władzami i instytucjami.

W poznańskiej Bibliotece Uniwersyteckiej funkcjonował, utworzony już w marcu 1945 r., Referat Zabezpieczania i Segregacji Zbiorów. Pracownicy w pierwszej kolejności przystąpili do ochrony księgozbiorów znajdujących się na obszarze miasta, a następnie w terenie. Posiadali specjalne upoważnienia wystawione przez dyrektora Aleksandra Birkenmajera, a także Ministerstwo Oświaty. Do ich podstawowych zadań należało zdobywanie wszelkich wiadomości o miejscach, w których występowały księgozbiory prywatne, instytucjonalne, przejęte przez państwo w wyniku reformy rolnej oraz inne. Informacje napływały z Kuratorium Okręgu Szkolnego Poznańskiego, Zarządu Państwowych Nieruchomości Ziemskich w Poznaniu, Ministerstwa Oświaty, starostw, a także od inspektorów szkolnych, nauczycieli, żołnierzy i innych osób. Po sprawdzeniu wiadomości zabezpieczano zbiory na miejscu oraz zwożono je, w miarę możliwości, do składnic. Następnie książki segregowano, z uwzględnieniem ich proweniencji, i dzielono. Sporządzono specjalne kartoteki, w tym dla bibliotek istniejących przed wybuchem wojny na terenie województw poznańskiego i pomorskiego. Podstawowe informacje czerpano ze Zbiorów Polskich Edwarda Chwalewika oraz Bibliotek wielkopolskich i pomorskich. Tak więc na postawione wcześniej pytanie należy odpowiedzieć twierdząco - ogłoszona drukiem praca Grycza miała zastosowanie w praktycznym działaniu. Przez analogię można przypuszczać, że służyła pomocą dla osób kierujących ochroną i w innych regionach Polski. W oparciu o tę publikację prowadzono prace w różnych ośrodkach na terenie kraju, dostosowując ją do istniejących lokalnych warunków. Nie wszystkie zawarte w książce propozycje miały zastosowanie z powodu licznych występujących trudności, w tym finansowych, lokalowych czy komunikacyjnych. Doświadczenie zdobywano podczas codziennej pracy, dostosowując działania do możliwości. Stąd też cel, związany z ochroną zbiorów bibliotecznych, osiągano różnymi drogami. $\mathrm{W}$ prowadzonych działaniach na terenie kraju można dostrzec wiele podobieństw, ale też i różnic.

Józef Grycz konsekwentnie realizował nakreślony przez siebie program. Intensywnie przygotowywał nowe zarządzenia z myślą o trwającej ochronie zbiorów bibliotecznych oraz odbudowie polskich bibliotek. Świadczą o tym m.in. jego osobiste zapiski, przechowywane w Zbiorach Specjalnych Biblioteki Narodowej. Przykładowo w maju 1945 r., oprócz prac bieżących, opracował: wskazówki dla zabezpieczenia zbiorów bi- 
bliotecznych i odbudowy bibliotek oraz instrukcję w tej samej sprawie, projekt ustawy o egzemplarzu obowiązkowym, projekt pisma do Ministra Skarbu o księgozbiorach opuszczonych lub porzuconych, projekt Naczelnej Dyrekcji Bibliotek ${ }^{31}$.

W uzasadnieniu projektu zarządzenia Ministerstwa Oświaty o opiece nad książką dawną, w maju 1945 r., Grycz podał: „Wśród strat wojennych naszych bibliotek najdotkliwsze są w dziedzinie zabytków, tj. rękopisów i starych druków, a to ze względu na ich rzadkość lub jedność. Zasługują one i wymagają szczególnej opieki, opartej o pełną ich ewidencję. Tę ewidencję /inwentaryzację/ starych druków przez 25 lat prowadził śp. Kazimi[er]z Piekarski, objąwszy nią ponad 100 bibliotek oraz ok. 90000 egzemplarzy. Materiały te spłonęły całkowicie w bibliotece Krasińskich na Okólniku" ${ }^{2}$. Zwłaszcza takie dzieła, w opinii Grycza, powinny zostać poddane szczególnej ochronie przez fachowców. Specjalistów w kraju jednak dotkliwie brakowało. Wobec tego rozpoczął organizowanie kursów szkoleniowych, w których był również wykładowcą ${ }^{33}$.

Konsekwentnie dążył do ujednolicenia i skoordynowania prowadzonych prac w ramach Ministerstwa Oświaty oraz współpracy z innymi instytucjami zabezpieczającymi zbiory. W połowie maja 1945 r. postanowił zaproponować powołanie „naczelnego zarządcy zbiorów bibliotecznych" 34 . Była to zapowiedź utworzenia niespełna rok później Naczelnej Dyrekcji Bibliotek.

W sprawozdaniu, za okres od 1 kwietnia do 25 lipca 1945 r. ${ }^{35}$, do najważniejszych i najpilniejszych zadań ponownie zaliczył zabezpieczenie

31 J. Grycz - Materiały do działalności publicznej; Sprawozdania i plany pracy, BN, rps akc. $14927 / 1$.

$32 \mathrm{~J}$. Grycz - Materiały do działalności publicznej; Uzasadnienie do projektu zarzadzenia Ministra Oświaty o opiece nad książka dawną, [Warszawa] 22 V 1945, BN, rps akc. 14927/1.

${ }^{33} \mathrm{~Np}$. J. Grycz razem z A. Kawecką byli wykładowcami dwutygodniowego kursu przygotowawczego dla pracowników bibliotecznych w zakresie dawnej książki, który odbył się we wrześniu 1945 r. w Kórniku. Naczelny dyrektor przewodniczył Komisji Egzaminacyjnej dla kandydatów na stanowiska I i II kategorii w państwowej służbie bibliotecznej, ustanowionej decyzją ministra Czesława Wycecha, na okres 1946-1947 r. Informował o planach Ministerstwa Oświaty zorganizowania przez Aleksandra Birkenmajera wyższej szkoły bibliotekarskiej w Krakowie, przeznaczonej dla bibliotekarzy naukowych pracujących w bibliotekach naukowych i powszechnych: „Więc i zagadnienia oświaty i czytelnictwa pedagogiki bibliotecznej itd. - związane z pracą bibliotekarstwa powszechnego na stopniu naukowym musiały by być uwzględnione. Obok tego pożądana specjalizacja: rękopisy, starodruki, grafika, kartografia - bardzo potrzebne, bo tego nigdzie nauczyć się obecnie nie można. Tu Kraków bardzo się nadaje, bo są zbiory i wykładowcy" (J. Grycz do A. Birkenmajera, Warszawa 18 VI 1947, BJ rps, Przyb. 572/75).

34 J. Grycz do A. Birkenmajera, Warszawa 15 V 1945, BJ, rps Przyb. 572/75.

35 J. Grycz - Materiały do działalności publicznej; Sprawozdania i plany pracy - BN, rps akc. $14927 / 1$. 
księgozbiorów. W tym czasie opracował m.in.: po wcześniejszym uzgodnieniu stanowisk z Ministerstwem Rolnictwa i Reform Rolnych, zarządzenie w sprawie przejęcia i dalszego postępowania $\mathrm{z}$ księgozbiorami podworskimi; w wyniku porozumienia z Ministerstwem Skarbu - zarządzenie w sprawie zabezpieczenia i zużytkowania księgozbiorów opuszczonych i porzuconych. Wydał drukiem Wskazówki dla prowadzacych akcje zabezpieczenia bibliotek i zbiorów bibliotecznych. Opracował także: ustawę o obowiązkowym dostarczaniu druków dla celów bibliotecznych, uchwałę o utworzeniu Naczelnej Dyrekcji Bibliotek, projekt rozporządzenia o Państwowej Radzie Książki, projekt ustawy o bibliotekach. Poza tym, w ramach Wydziału Bibliotek, doprowadził do utworzenia Oddziału Dawnej Książki ${ }^{36}$.

Kolejne miesiące były również pracowite. Przygotował zarządzenie w sprawie zabezpieczenia i zużytkowania księgozbiorów opuszczonych lub porzuconych, projekt dekretu o księgozbiorach podworskich, projekt zarządzenia o znajdujących się w handlu książkach bibliotecznych. Opiniował projekt dekretu o rejestracji i zakazie wywozu dzieł sztuki. Należy podkreślić, iż w myśl Ustawy z 6 V 1945 r. o majątkach opuszczonych i porzuconych ${ }^{37}$, zabezpieczeniu podlegały księgozbiory stanowiące tzw. mienie opuszczone i porzucone. Do pierwszej grupy zaliczono te, które w związku z wojną rozpoczętą 1 września 1939 r. nie znajdowały się w posiadaniu właścicieli; natomiast w skład drugiej wchodziły zbiory, które były własnością lub w posiadaniu państwa niemieckiego, obywateli niemieckich bądź osób zbiegłych do nieprzyjaciela ${ }^{38}$. Określenie „mienie opuszczone", odnoszące się przede wszystkim do własności ziemian, niesłuszne sugeruje, iż zrezygnowali oni ze swoich majątków. W wyniku wprowadzanych zmian ustrojowych w Polsce nie mogli wrócić do swoich siedzib, a nawet zamieszkać w pobliżu własnych dóbr.

Podział kompetencji, związany z prowadzeniem działań na rzecz ochrony zbiorów bibliotecznych przez różne instytucje i organy państwowe, okazał się niepraktyczny. Wobec tego Ministerstwo Oświaty, po porozumieniu z Ministerstwem Skarbu oraz Ministerstwem Rolnictwa i Reform Rolnych, objęło swoją wyłączną opieką wszystkie księgozbiory opuszczone i poniemieckie. W związku z tym minister oświaty wydał

36 Tamże.

37 „Dziennik Urzędowy Ministerstwa Oświaty” (dalej cyt. Dz. Urz. Min. Ośw.), 1945, nr 17, poz. 97.

38 Zarządzenie Ministerstwa Oświaty z dnia 4 sierpnia 1945 r. w sprawie zabezpieczenia i zużytkowania księgozbiorów opuszczonych lub porzuconych, Dz. Urz. Min. Ośw., 1945, nr 4, poz. 115 . 
dwa zarządzenia: z 9 VII 1945 r. w sprawie przejęcia księgozbiorów podworskich od pełnomocników do spraw reformy rolnej ${ }^{39}$ oraz z 4 VIII 1945 r. w sprawie zabezpieczenia i zużytkowania księgozbiorów opuszczonych lub porzuconych ${ }^{40}$. Nowo zorganizowane działania spowodowały w krótkim czasie poddanie ochronie wielomilionowych zbiorów.

Józef Grycz utrzymywał kontakty osobiste oraz korespondencyjne z przedstawicielami Ministerstwa Oświaty działającymi w terenie, np.: Stefanem Burhardtem, Antonim Knotem, Marianem Pelczarem. Starał się im pomóc w sygnalizowanych problemach oraz informował o bieżących pracach i zamierzeniach Ministerstwa Oświaty. Jednym z nich był Aleksander Birkenmajer, zabiegający o wsparcie m.in. spraw kadrowych Biblioteki Uniwersyteckiej w Poznaniu oraz o zdobycie środków finansowych potrzebnych na zabezpieczanie księgozbiorów. Józef Grycz, w liście z 13 IV 1945 r., oznajmit:

Pierwsza rzecz jest jasna, natomiast druga wymaga uprzedniego wyjaśnienia. Mianowicie Minister podczas bytności w Krakowie poruczył zabezpieczanie księgozbiorów bibliotekom uniwersyteckim, nie licząc się z tym, że Ministerstwo ten obowiązek już nałożyło na kuratorów okręgów szkolnych i powiatowych inspektorów szkolnych. Wynikły stąd nieporozumienia w okręgu krakowskim i wczoraj Janiczek pokazywał mi pismo Ministra, uchylające jego zarządzenie co do bibliotek uniwersyteckich. Stąd wątpliwość u mnie, czy Janiczek będzie mógł potrzebne pieniądze zdobyć dla Biblioteki Uniwersytetu Poznańskiego. Muszę to dopiero sprawdzić, co może nastąpić w poniedziałek - wtorek, gdy będę na Pradze. Urzęduję bowiem na lewym brzegu Wisły w lokalu Biblioteki Publicznej na Koszykowej, a na Pradze w ogóle byłem zaledwie dwa razy. Zapewniam Pana jednak, że zrobię wszystko, co będzie możliwe ${ }^{41}$.

W korespondencji jest mowa o zarządzeniu wydanym w Krakowie 15 II 1945 r. przez ministra Stanisława Skrzeszewskiego, w sprawie zabezpieczenia bibliotek w województwach oswabadzanych z niewoli hitlerowskiej ${ }^{42}$. Minister ustanowił czterech okręgowych kierowników bibliotecznych, do zadań których należało przejmowanie oraz dalsza ochrona zbiorów bibliotecznych. Kierownikami zostali: dla woj. krakowskiego i kieleckiego - dyrektor Biblioteki Jagiellońskiej w Krakowie, woj. śląskiego - dyrektor Biblioteki Publicznej w Katowicach, woj. łódzkiego -

${ }^{39}$ Dz. Urz. Min. Ośw., 1945, nr 4, poz. 110.

${ }^{40}$ Dz. Urz. Min. Ośw., 1945, nr 4, poz. 115.

${ }^{41}$ J. Grycz do A. Birkenmajera, Warszawa, 13 IV 1945 - BJ rps, Przyb. 572/75.

42 Zarządzenie zostało wydane z inicjatywy członków Związku Bibliotekarzy Polskich przebywających w Krakowie. 
dyrektor Biblioteki Miejskiej w Łodzi, woj. poznańskiego i pomorskiego - dyrektor Biblioteki Uniwersyteckiej Poznaniu. Decyzja ta doprowadzała do konfliktów na obszarze podległym Bibliotece Jagiellońskiej, pomiędzy tą placówką a kuratorium. Konieczne w tym zakresie było uzgodnienie stanowisk i współpraca. Dochodziło do niej w różnych zakątkach kraju. Inspektoraty i kuratoria przekazywały delegatom zabezpieczone zbiory oraz informowały o ich występowaniu na swoim terenie. Kuratoria oddawały część przyznanych przez Ministerstwo środków na potrzeby okręgowych kierowników bibliotecznych. Jednak były to kwoty niewystarczające w stosunku do olbrzymich potrzeb, o czym świadczy przykładowo fragment listu skierowanego do Józefa Grycza: „Nie wiem, skąd pokryję resztę transportów z Wicimic i z Dobrej (Pomorze Zachodnie), które lada dzień powinny nadejść koleją. A tymczasem nie ma tygodnia, żebym nie otrzymał nowych zgłoszeń [...]. Jeden z nich załączam w odpisie; dotyczy niewątpliwie rzeczy cennych! Serce mnie boli, że nie mogę tam interweniować [...]. Pieniędzy, pieniędzy i jeszcze raz pieniędzy!"43. Józef Grycz, wspierany przez naczelnika Wydziału Bibliotek Józefa Janiczka, z którym ściśle współpracował, zabiegał w Ministerstwie Oświaty o pozyskanie większych środków finansowych. Jednak, jak to określił: „Z pieniędzmi jest dość ciasno"44. Sytuacja ta nie ulegnie zmianie przez cały okres trwania akcji zabezpieczania księgozbiorów, tj. do 1949 r.

Wprowadzenie oraz realizacja przyjętych rozporządzeń prawnych, opracowanych w znacznym stopniu przez Józefa Grycza, okazała się zadaniem niełatwym. Liczne trudności, jak i zapewne zmiany ustrojowe w Polsce sprawiły, że latem 1945 r. nosił się zamiarem opuszczenia Ministerstwa Oświaty: „Chciałem uciec do Krakowa, gdzie proponowali mi kierownictwo Biblioteki Miejskiej, ale Minister nie puścił mnie"45.

Zwłaszcza w zniszczonej Warszawie, borykającej się z problemami komunikacyjnymi, lokalowymi i innymi, wyjątkowo trudno było prowadzić wszelkie sprawy, w tym związane z ochroną zbiorów. Pomimo licznych przeszkód Józef Grycz postanowił ostatecznie pozostać: „Ja też wolałbym pracować w jakiejś bibliotece i w 'normalnym' mieście, a siedzę w Ministerstwie - pro publico bono" 46 . Był człowiekiem odpowiedzialnym. Doskonale zdawał sobie sprawę z wagi i znaczenia podejmowanych działań.

${ }^{43}$ J. Grycz - Korespondencja; A. Birkenmajer do J. Grycza, Poznań, 11 XII 1945 BN, rps akc. 14966/2.

${ }^{44}$ J. Grycz do A. Birkenmajera, Warszawa 1 IX 1945 - BJ, rps Przyb. 572/75.

45 Tamże.

46 Tamże. 
Wziął udział, razem z żoną Alodią Kawecką-Gryczową, w pierwszej powojennej konferencji okręgowych wizytatorów bibliotek, zorganizowanej przez Józefa Janiczka, która trwała od 24 do 27 październiku 1945 r. w Pabianicach. Debata ta miała ogromne znaczenie dla scentralizowania działań związanych z ochroną zbiorów bibliotecznych. Oprócz przedstawicieli Ministerstwa Oświaty i wizytatorów, reprezentujących kuratoria okręgów szkolnych, w czterodniowej konferencji uczestniczyli przedstawiciele bibliotek naukowych biorący udział w akcji zabezpieczenia księgozbiorów. Byli wśród nich między innymi Aleksander Birkenmajer z Poznania (Biblioteka Uniwersytecka) oraz Stanisław Sierotwiński z Krakowa (Biblioteka Jagiellońska). Materiały z tego spotkania zostały opublikowane rok później ${ }^{47}$. Uczestnicy wysłuchali referatów, m.in. Ksawerego Świerkowskiego, pt. Zabezpieczanie księgozbiorów poniemieckich i podworskich oraz sprawa ich zużytkowania. Po tym wystąpieniu, jak wspomniano, wywiązała się ożywiona dyskusja, która wskazywała na potrzebę zapobieżenia nadużyciom związanym z szabrem książką, konieczność opracowania instrukcji dotyczącej selekcji zgromadzonych zbiorów i inwentaryzacji. Ze względu na dużą ilość książek proweniencji poniemieckiej podnoszono kwestię czasowego zakazu handlu takimi dziełami. W przedstawionym sprawozdaniu z działalności Kuratorium Okręgu Szkolnego Poznańskiego, za okres od końca kwietnia do 15 października 1945 r., podkreślono, że ogromny napływ tych dzieł przyczynił się aż do trzykrotnego wzrostu, w porównaniu z okresem przedwojennym, ilości księgarń w Poznaniu ${ }^{48}$. Tylko w tym okręgu, w okresie zaledwie kilku miesięcy, zabezpieczono około 40 tys. książek polskich oraz ok. 700 tys. książek poniemieckich ${ }^{49}$. Zgoła odmiennie przedstawiała się sytuacja na terenie podległym Kuratorium Okręgu Szkolnego Lubelskiego:

[...] wyniki nasze w akcji zabezpieczenia księgozbiorów opuszczonych i porzuconych są więcej niż skromne. Zanim przyszło do porozumienia między Ministerstwem Oświaty a Ministerstwem Kultury i Sztuki oraz Ministerstwem Informacji i Propagandy księgozbiory, o których mowa, zostały w przeważającej większości „rozparcelowane”. Jednym z dowodów jest protokół zdawczo-odbiorczy podpisany przez Powiatowy Oddział Informacji i Propagandy oraz Inspektora Szkolnego w Hrubieszowie: „Wyżej wymieniony przekazany księgozbiór

${ }^{47}$ Aktualne zagadnienia bibliotekarskie. Pierwsza powojenna konferencja okregowych wizytatorów bibliotek $w$ dniach 24-27 października 1945 r. w Pabianicach, Warszawa 1946.

${ }^{48}$ Tamże, s. 113.

49 Tamże. 
stanowi tylko część zabranej przez ob. Chwałę Antoniego i jego współpracownika z majątku Raciborowice powiat Hrubieszów. Zabranie księgozbioru z Raciborowic powiat Hrubieszów nastąpiło bez polecenia kierownika tutejszego Urzędu Propagandy. Druga część zabranego księgozbioru, stanowiąca niepomiernie większą wartość od przekazanej, została rozprowadzona przez ówczesnego kierownika Propagandy bez śladów i zapisków"50.

W Pabianicach Józef Grycz przybliżył problem przygotowywanej ustawy o bibliotekach i projekt organizacji władz bibliotecznych. Aktywnie uczestniczył w rozmowach dotyczących ochrony zbiorów bibliotecznych. Wnikliwie przysłuchiwał się wystąpieniom. Dyskusja bowiem dostarczyła Ministerstwu Oświaty niezbędnych materiałów do przygotowania nowych zarządzeń. Wtedy też, podczas pabianickiego spotkania, zapadła niezwykle ważna decyzja dotycząca ustanowienia Delegatury Ministerstwa Oświaty w Krakowie. O postanowieniu jej utworzenia nie znajdziemy jednak żadnego śladu we wspomnianej publikacji. Działalność delegatury, która rozpoczęła funkcjonowanie 1 XII 1945 r., utajniono, w obawie przed niemieckimi roszczeniami rewindykacyjny$\mathrm{mi}^{51}$. Pracami kierował Stanisław Sierotwiński, który z zespołem liczącym około 30 osób przez okres 13 miesięcy poddał ochronie w sześciu okręgach (I - krakowski, II - wrocławski, III - szczeciński, IV - gdański, V olsztyński, VI - lubuski) około 5,5 miliona książek ${ }^{52}$. Zabezpieczył w 171 punktach dzieła, w tym m.in. w Krzeszowie część najcenniejszych zbiorów Preussische Staatsbibliothek (tzw. „Berlinkę”), przewiezionych przez Niemców w czasie wojny, którą z zachowaniem ścisłej tajemnicy przetransportowano do Biblioteki Jagiellońskiej. Wybór Krakowa na siedzibę Delegatury Ministerstwa Oświaty nie był przypadkowy. W przeciwieństwie do Warszawy miasto nie zostało zniszczone podczas okupacji i dysponowało pomieszczeniami mogącymi pomieścić liczne przywożone zbiory biblioteczne. Stolica Polski pełniła natomiast funkcję ośrodka decyzyjnego związanego z ochroną zbiorów bibliotecznych.

50 Tamże, s. 130-131.

${ }^{51}$ W sprawozdaniu, przedłożonym w 1946 r. ministrowi oświaty Czesławowi Wycechowi, napisał: „Duże, ważne i trudne zadanie zabezpieczenia księgozbiorów opuszczonych i poniemieckich wymagało ustanowienia specjalnego delegata [podkreślenie Józefa Grycza - R. N.] dla tych spraw. Oprócz Centrali w Krakowie delegatura posiada swe placówki we Wrocławiu, Szczecinie, Gdańsku i Olsztynie” (Józef Grycz, Materiały do działalności publicznej; Biblioteka, [Warszawa] 1946, BN, rps akc. 14927/3).

${ }^{52}$ Szerzej na temat ochrony zbiorów przez Stanisława Sierotwińskiego zob. R. Nowicki, Dziatalność Stanistawa Sierotwińskiego w latach 1945-1946 jako delegata Ministerstwa Oświaty do zabezpieczania ksiegozbiorów opuszczonych i porzuconych na Ziemiach Zachodnich, „Roczniki Biblioteczne”, 50:2006, s. 13-44. 
Zwożenie dzieł napotykało na różne przeszkody. Często dawały o sobie znać problemy komunikacyjne, które wydłużały w czasie transport zbiorów oraz ograniczały w znacznym stopniu mobilność samych ratowników książki. Dość wspomnieć, iż niektórzy uczestnicy pabianickiej konferencji wracali do swoich miejsc pracy z przygodami: „Długo je byłoby opisywać - ale rezultat był ten, że z Łodzi do Poznania jechałem ni mniej, ni więcej, tylko 50 godzin i dobrnąłem tutaj [tj. do Poznania] dopiero o godz. 9-tej rano, nieogolony, brudny, zawszawiony i niewiarygodnie zmęczony" 53 - wyznał Aleksander Birkenmajer.

Spotkanie w Pabianicach stanowiło dla uczestników dodatkową okazję przypomnienia o istniejących problemach, również w wersji pisanej. Przykładowo Józef Grycz w liście z 3 listopada 1945 r. do dyrektora Biblioteki Uniwersyteckiej w Poznaniu wspomniał ,sprawy z karteczki pabianickiej" 54 . Otrzymał ją od Aleksandra Birkenmajera, z prośbą o przyspieszenie ich załatwienia w Ministerstwie Oświaty. Na liście tej znajdowała się m.in. pozycja dotycząca przyznania większych środków na zabezpieczanie zbiorów. Miesiąc później dyrektor Biblioteki Uniwersyteckiej informował: „Doświadczenie, jakie poczyniliśmy z akcją tzw. zabezpieczania, są po prostu odstraszające. Nie potrzebuję Panu tłumaczyć, ile można było zrobić, a ile faktycznie dało się zrobić - przy tym wiecznym dobijaniu się o każdy dziesiątek tysięcy, przy tym wiecznym czekaniu na wypłatę przyrzeczonych już funduszów"55. Józef Grycz nie pozostawał obojętny wobec takich sygnałów. Podejmował interwencje w Ministerstwie Oświaty. Godnym podkreślenia jest fakt, iż w grudniu 1945 r., kiedy zachorował, Alodia Kawecka-Gryczowa zabiegała w Ministerstwie o wsparcie ${ }^{56}$. Żona naczelnego dyrektora bibliotek aktywnie uczestniczyła w ochronie zbiorów bibliotecznych i wspierała męża. Wspomnę w tym miejscu jedynie, że 16 lipca 1945 r. wyruszyła w pionierskiej grupie na Dolny Śląsk, wspólnie z Ksawerym Świerkowskim, Wandą Ładniewską, Wacławem Aluchna, Bogdanem Horodyskim, Józefem Janiczkiem (jr.) i Mieczysławem Zadrożnym, celem ochrony i rewindykacji zbiorów wywiezionych ze stolicy do Adelina (Zagrodna) ${ }^{57}$.

53 J. Grycz - Korespondencja; A. Birkenmajer do J. Grycza, Poznań, 30 X 1945 (BN, rps akc. 14966/2.

54 J. Grycz do A. Birkenmajera, Warszawa 3 XI 1945 - BJ rps, Przyb. 572/75.

55 J. Grycz - Korespondencja; A. Birkenmajer do J. Grycza, Poznań, 4 XII 1945 - BN, rps akc. 14966/2.

56 J. Grycz do A. Birkenmajera, Warszawa, 19 XII 1945 - BJ rps, Przyb. 572/75.

${ }^{57}$ Maciej Dąbrowski, Ksawerego Świerkowskiego walka o dobra kultury, „Roczniki Biblioteczne", 24:1980, z. 1, s. 120. 
Realizacja planu stworzonego przez Józefa Grycza przynosiła wymierne korzyści. Na terenie kraju powstały różnej wielkości składnice książek zabezpieczonych. Zgromadzony wielomilionowy materiał biblioteczny wymagał segregacji. Temu celowi służyła specjalna instrukcja Ministerstwa Oświaty, z dnia 25 I 1946 r., w sprawie postępowania z księgozbiorami zabezpieczonymi ${ }^{58}$. Jej tekst został opracowany przez Józefa Grycza.

W 1946 r. Grycz ogłosił na łamach „Przeglądu Bibliotecznego” obszerny artykuł, pt. Problemy biblioteczne obecnej doby, w którym m.in. dokonał podsumowania prowadzonej akcji zabezpieczania zbiorów bibliotecznych $^{59}$. Zasygnalizował w nim osiągnięcia, jak również występujące problemy. Ten rok, podobnie jak poprzedni, okazal się niezwykle pracowity. Józef Grycz, w prywatnej korespondencji, informował: „Mój urlop znowu (po raz trzeci) przepada. Najpierw byłem zajęty w komisji polsko-ukraińskiej dla przejęcia Ossolineum, jutro wyjeżdżam na parę dni do Wrocławia na dużą konferencję w sprawie przydziału zbiorów naukowych na Śląsku, potem preliminarz budżetowy na 1947 [r.] i rozporządzenie wykonawcze do dekretu o bibliotekach - i sierpień się kończy. A w pierwszych dniach września z p. Janiczkiem musimy objechać Dolny Śląsk"60.

W uwagach do budżetu na 1947 r. domagał się zwiększonych kwot, z proponowanych $9 \mathrm{mln}$ zł do $13 \mathrm{mln}$ zł, na prowadzenie działań zbiornic-sortowni oraz Biura Międzynarodowej Wymiany Wydawnictw. Argumentował następująco: „Wobec zniszczenia bibliotek wskutek wojny i okupacji zaopatrzenie ich w zbiory jest sprawą najpilniejszą. Możemy i musimy tu m.in. korzystać z księgozbiorów opuszczonych i poniemieckich oraz darów płynących w dużych ilościach z zagranicy. Akcja zabezpieczania, segregowania i repartycji pierwszych a przejmowania i rozdzielania drugich wymaga oczywiście pewnych kredytów w budżecie, które jednak opłacają się nieomal stokrotnie"61.

${ }^{58}$ Dz. Urz. Min. Ośw., 1946, nr 1, poz. 13.

${ }^{59}$ Przegl. Bibliot., 14:1946, s. 4-24.

${ }^{60}$ J. Grycz do A. Birkenmajera, Warszawa 6 VIII 1946 - BJ rps, Przyb. 572/75. Na Śląsku wystąpił problem związany m.in. $\mathrm{z}$ wywozem $\mathrm{z}$ tego obszaru zbiorów zabezpieczonych, w tym biblioteki Schaffgotschów. Za pozostawieniem na miejscu cennego księgozbioru stanowczo opowiadała się Rada Naukowa Instytutu Śląskiego w Katowicach. Spór trwał do początku 1949 r. W myśl umowy, podpisanej 24 stycznia tego roku w Cieplicach, cześć dzieł z biblioteki Schaffgotschów skierowano do Biblioteki Narodowej, a część do Wrocławia (Silesiaca) - R. Nowicki, Zabezpieczanie księgozbiorów po II wojnie światowej $w$ Polsce, „Napis”, Seria XI, 2005, s. 285-286.

61 J. Grycz - Materiały do działalności publicznej; Budżet Bibliotek na R. 1947, [Warszawa] 27 I 1947 (BN, rps akc. 14927/3). 
W 1947 r. Ministerstwo Oświaty przystąpiło do drugiego etapu gromadzenia i zużytkowania zbiorów zabezpieczonych, to jest segregacji i repartycji ${ }^{62}$. Na terenie kraju zostały utworzone zbiornice-sortownie. Instytucje tego rodzaju funkcjonowały w Gdańsku, Katowicach, Krakowie, Poznaniu ${ }^{63}$, Szczecinie ${ }^{64}$ i Wrocławiu. Do ich zadań należało: penetrowanie terenu celem odszukania i przetransportowania materiałów bibliotecznych do odpowiedniej zbiornicy, magazynowanie zbiorów, segregacja zgodnie z instrukcją z 25 stycznia 1946 r. oraz przekazywanie książek na podstawie upoważnień Ministerstwa Oświaty.

Ministerstwo zabiegało również o odzyskanie zbiorów wywiezionych do innych państw. Cenne druki i rękopisy, pochodzące m.in. z dawnej Biblioteki Załuskich, trafiły do Görbitsch, niedaleko Frankfurtu nad Odrą. Józef Grycz zanotował: „Na miejscu znaleziono i reewakuowano tylko 2 wagony książek i niewiele rękopisów. Najwartościowsze zbiory zostały wywiezione przez jednostki Armii Czerwonej do Rosji i od dłuższego czasu czyni się zabiegi o ich odzyskanie. Energiczne starania na drodze dyplomatycznej prowadzi się również o repatriację bibliotek i zbiorów pozostałych na ziemiach odstąpionych ZSRR"65. Rewindykowanie zbiorów od władz radzieckich, traktujących książki jako materiał „trofiejny”, okazało się zadaniem trudnym lub niemożliwym.

Naczelny dyrektor bibliotek przypuszczał, że akcja zabezpieczenia i zużytkowania zbiorów w 1948 r. zostanie zakończona ${ }^{66}$. Trzeba przy-

62 J. Grycz - Materiały do działalności publicznej; Notatka (BN, rps akc. 14927/4).

${ }^{63}$ Przykładowo w stolicy Wielkopolski wystąpiły trudności ze znalezieniem odpowiedniego lokum dla potrzeb zbiornicy. Na ten cel zamierzano pozyskać pomieszczenia poznańskiego Zamku. Wobec sprzeciwu władz miasta sprawę skierowano do prezydenta Polski. Józef Grycz informował Aleksandra Birkenmajera: „Niedobrze jest z Zamkiem. Kancelaria Prezydenta odpisała, aby do chwili zdecydowania o przeznaczeniu Zamku zbiornicę urządzić gdzie indziej. Czy i jakie ma Pan możliwości? Nie znam zupełnie warunków poznańskich, ale może na razie prowadzić sortowanie partiami w jakimś mniejszym lokalu, byle zacząć i wypychać do bibliotek przesortowany materiał” (J. Grycz do A. Birkenmajera, Warszawa, 25 III 1947 - BJ rps, Przyb. 572/75). Zbiornica Księgozbiorów Zabezpieczonych w Poznaniu powstała przy Bibliotece Uniwersyteckiej. Jej pierwszy kierownik Aleksander Birkenmajer utworzył Filię Zbiornicy w Krotoszynie. W Poznaniu wszystkie lokale przeznaczone na składnice książek były przepełnione dziełami zabezpieczonymi i zwiezionymi z terenu.

64 Zob. R. Nowicki, Rezultaty działalności Zbiornicy Ksiegozbiorów Zabezpieczonych w Szczecinie w latach 1947-1950, „Roczniki Biblioteczne”, 51:2007, s. 169-188.

65 J. Grycz - Materiały do działalności publicznej; Biblioteka, [Warszawa] 1946 - BN, rps akc. $14927 / 3$.

66 J. Grycz, Zamierzenia Naczelnej Dyrekcji Bibliotek na rok 1948 - BN, rps akc. $14927 / 3$. 
znać, że najintensywniejsze prace prowadzono w latach 1945-1946. Wtedy też poddano ochronie najwartościowsze księgozbiory. Z terenu nadal napływały informacje o książkach, oczekujących na zwiezienie. Nie miały one jednak takiego znaczenia, jak zgromadzone już w zbiornicach-sortowniach. Akcja ochrony zbiorów dobiegała zatem końca. Wobec tego do głównych zadań należała dalsza realizacja postanowień dekretu o bibliotekach i opiece nad zbiorami bibliotecznymi. Wysitki Józefa Grycza zmierzały do dokończenia organizacji sieci bibliotek powiatowych oraz budowy sieci bibliotek miejskich i gminnych, ze szczególnym uwzględnieniem ziem przyłączonych do Polski w wyniku postanowień Wielkiej Trójki. Planował specjalizację bibliotek naukowych, ujętych w sieć, którym w zależności od potrzeb, przydzielane będą materiały ze zbiorów zabezpieczonych ${ }^{67}$.

W 1949 r. akcja ochrony zbiorów została zakończona. W tym samym roku Józef Grycz, z powodów politycznych, przestał pracować w Ministerstwie Oświaty. Władze zarzucały bibliologowi rzekome „uchybienia służbowe”68, czy przykładowo wyrażenie zgody na „zwolnienie zbiorów bibliotecznych proweniencji belgijskiej i holenderskiej bez uzgodnienia tej sprawy z Wydziałem Stosunków z Zagranicą"69. Na uwagę zasługuje fakt, iż bibliotekarze w terenie dokonywali zwrotu dzieł prawowitym właścicielom, tj. osobom prywatnym i instytucjom, „za milcząca aprobatą byłego Naczelnego Dyrektora Bibliotek, ob. Dr. Grycza"70.

Alodia Kawecka-Gryczowa w 1959 r., kilka lat po śmierci męża, napisała: „Lecz intrygi i narastająca zła atmosfera ogólna doprowadziły do usunięcia Grycza z zajmowanego stanowiska. Wskutek obsadzenia go następnie przez niefachowców, nie rozumiejących znaczenia ośrodka, o który walczył Grycz przez cały ciąg swego długiego urzędowania, doszło w rezultacie do likwidacji Naczelnej Dyrekcji, do rozbicia i pomniej-

${ }^{67}$ Według J. Grycza księgozbiory zabezpieczone i rewindykowane winny zasadniczo służyć do uzupełnienia bibliotek naukowych. Odbudowa bibliotek szkolnych i powszechnych miała głównie polegać na dostarczaniu wydanych po II wojnie polskich książek J. Grycz, Biblioteka, [Warszawa] 1946 - BN, rps akc. 14927/3.

68 J. Grycz - Materiały biograficzne; Pismo Ministerstwa Oświaty Nr I Pers-2368/49, Warszawa 1 II 1949 - BN, rps akc. 14917.

${ }^{69}$ Pismo Ministerstwa Oświaty Nr I Pers-4827/49, Warszawa 8 III 1949 - BN, rps akc. $14927 / 3$.

${ }^{70}$ R. Nowicki, Działalność Aleksandra Birkenmajera..., s. 220. Zob. także Hanna Łaskarzewska, Zbiory przejęte i przemieszczone w bibliotekach polskich po drugiej wojnie światowej. Problemy wtasności, przykłady rozwiazań, [w:] Wtasność a dobra kultury, pod red. G. Czubek i P. Kosiewskiego, Warszawa 2006, s. 15-47. 
szenia znaczenia bibliotekarstwa, z którego to układu dotychczas nie może się podnieść"71.

Z zasygnalizowanych zaledwie faktów wynika, iż w latach 1945-1949 Józef Grycz, z ramienia Ministerstwa Oświaty, centralnie kierował ochroną zbiorów bibliotecznych. Przyczynił się do podjęcia zorganizowanych działań w skali kraju. Ogłosił Wskazówki dla prowadzacych akcje zabezpieczenia bibliotek i zbiorów bibliotecznych, które ułatwiły i usprawniły pracę $\mathrm{w}$ terenie. Publikacja ta miała nie tylko walory teoretyczne, ale również praktyczne. Zabiegał, z pozytywnym skutkiem, o stworzenie nadrzędnego ośrodka kierującego działaniami na rzecz ochrony zbiorów. Doprowadził do powstania Naczelnej Dyrekcji Bibliotek w Ministerstwie Oświaty skupiającej wszystkie sprawy biblioteczne, w tym zabezpieczania księgozbiorów. Jego koncepcje organizacyjne okazały się słuszne, chociaż nie wszystkie zostały zrealizowane. Był inicjatorem i autorem ważnych dokumentów prawnych regulujących powojenną ochronę zbiorów bibliotecznych. Treść niektórych z nich może budzić kontrowersje. Należy w tym wypadku pamiętać i wziąć pod uwagę przy ocenie, skomplikowane czasy, w których przyszło żyć Józefowi Gryczowi. Zmiany o charakterze ustrojowym i politycznym w Polsce, która po II wojnie światowej znalazła się w strefie wpływów Związku Radzieckiego, były wprowadzane odgórnie. Nie miał na nie najmniejszego wpływu biblio$\log$, świadomie prowadzący działania pro publico bono. Kompromis okazał się możliwy tylko do pewnego momentu, tj. 1949 r. Grycz niewątpliwie wykazywał głęboką troskę o losy książki. Umiejętnie potrafił współpracować z innymi, przez których był wysoko ceniony za profesjonalizm. W pracy napotykał na liczne trudności, których w powojennej rzeczywistości nie sposób było uniknąć. W wyniku nakreślonego przez bibliotekarza planu zabezpieczono zbiory liczące ogółem kilkanaście milionów tomów. Rola Józefa Grycza w powojennej ochronie zbiorów bibliotecznych była więc ogromna. Należy do grona szczególnie zasłużonych osób - swoją postawą przyczynił się w sposób wyjątkowy do rozwoju bibliotekarstwa oraz kultury książki w Polsce. Jego bogata działalność i twórczość w pełni zasługują na podjęcie badań, które doprowadzą do powstania monografii poświęconej wybitnemu bibliologowi i ratownikowi książki.

71 J. Grycz - Materiały biograficzne; A. Kawecka-Gryczowa, Życiorys Józefa Grycza z 10 I 1959 r. - BN, rps akc. 14917. 
Summary

\section{The Role of Józef Grycz in Preserving Library Collections after World War II}

During the Second World War Polish cultural heritage suffered severe losses. Among the persons who played an important role in the recovery of extant library collections was Józef Grycz. While the hostilities were still raging, Grycz was busy working out theoretical measures to be undertaken after the war. When peace finally came, Grycz immediately stepped in to implement his wartime ideas. During the period 1945-1949, he was active in book collection preservation on behalf of the Ministry of Enlightenment. It was on his initiative that the Central Directorate of Libraries was called into existence, as a ministerial body responsible for library activities and the coordination of the all efforts in this respect undertaken by various institutions. He also published an instruction manual, which greatly facilitated works all over the country, and numerous official documents.

His activities can be divided into two phases: the first one (to the end of 1946) consisted chiefly in physical protection of the recovered materials, while the second, which started with the launching of the Central Directorate at the beginning of 1947, concentrated on creating of a number of warehouses, where books were gathered, sorted, registered, and allocated with their future location in mind. Alodia Kawecka-Gryczowa, Józef Grycz's wife, assisted him in those activities all along.

The tasks undertaken by Grycz were extremely complicated and difficult. He was constantly hindered by all kinds of problems, which in the post-war Polish reality were inevitable. Nevertheless, under his guidance the salvage process covered more than ten million volumes. The significance of Grycz's prominent personality in the preservation of Polish cultural heritage after World War II can hardly be overestimated. 